\title{
APRIL 1973
}

THIRTEENTH YEAR - No. 145
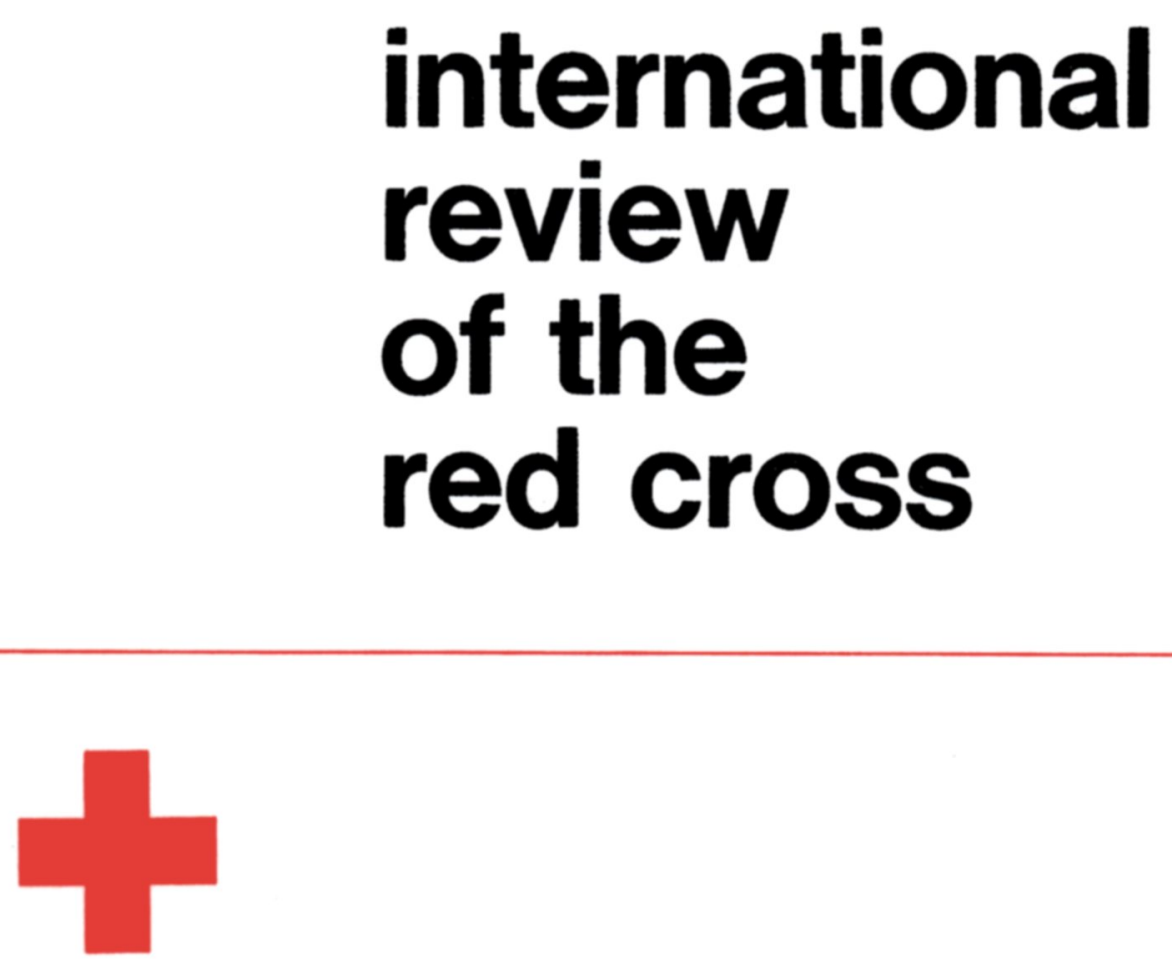

INTER ARMA CARITAS

\section{GENEVA}

INTERNATIONAL COMMITTEE OF THE RED CROSS FOUNDED IN 1863 


\section{INTERNATIONAL COMMITTEE OF THE RED CROSS}

MARCEL A. NAVILIE, President (member since 1967)

JEAN PICTET, Doctor of Laws, Chairman of the Legal Commission, Vice-President (1967)

HARALD HUBER, Doctor of Laws, Federal Court Judge, Vice-President (1969)

PAUL RUEGGER, Ambassador, President of the ICRC from 1948 to 1955 (1948)

GUILLAUME BORDIER, Certificated Engineer E.P.F., M.B.A. Harvard, Banker (1955)

HANS BACHMANN, Doctor of Laws, Winterthur Stadtrat (1958)

DIETRICH SCHINDLER, Doctor of Laws, Professor at the University of Zurich (1961)

MARJORIE DUVILLARD, Nurse (1961)

MAX PETITPIERRE, Doctor of Laws, former President of the Swiss Confederation (1961)

ADOLPHE GRAEDEL, member of the Swiss National Council from 1951 to 1963, former Secretary-General of the International Metal Workers Federation (1965)

DENISE BINDSCHEDLER-ROBERT, Doctor of Laws, Professor at the Graduate Institute of International Studies (1967)

JACQUES F. DE ROUGEMONT, Doctor of Medicine (1967)

ROGER GALLOPIN, Doctor of Laws, former Director-General (1967)

WALDEMAR JUCKER, Doctor of Laws, Secretary, Union syndicale suisse (1967)

VICTOR H. UMBRICHT, Doctor of Laws, Managing Director (1970) on special leave PIERRE MICHELI (1971)

Honorary members: Mr. JACQUES CHENEVIERE, Honorary Vice-President; Miss LUCIE ODIER, Honorary Vice-President; Messrs. CARL J. BURCKHARDT, PAUL CARRY, Mrs. MARGUERITE GAUTIER-VAN BERCHEM, Messrs. SAMUEL A. GONARD, EDOUARD de HALLER, PAUL LOGOZ, RODOLFO OLGIATI, FREDEERIC SIORDET, ALFREDO VANNOTTI, ADOLF VISCHER.

Directorate: Mr. JEAN-LOUIS LE FORT, Secretary-General.

Mr. CLAUDE PILLOUD, Director, Department of Principles and Law.

Mr. JEAN-PIERRE MAUNOIR, Assistant Director, Director of Operations ad interim. 


\section{INTERNATIONAL REVIEW OF THE RED CROSS}

APRIL 1973 - No. 145

\section{CONTENTS}

\begin{abstract}
INTERNATIONAL COMMITTEE OF THE RED CROSS
\end{abstract}

IN THE RED CROSS WORLD

MISCELLANEOUS
Dieter Fleck : The Employment of Legal Advisers and Teachers of Law in the Armed Forces .... 173 J.-A. Baumann: Medical Training for Disaster Situations $\ldots \ldots \ldots \ldots \ldots \ldots \ldots \ldots \ldots \ldots \ldots, 182$

External Activities :

Middle East - Asian sub-continent - DelegateGeneral's mission in Asia.............. 189 In Geneva:

Guests of the ICRC ................ 192

A Word of Clarification ............... 192

ICRC Activity in the Middle East in 1972 ....... 193 Increasing Dissemination of the Soldier's Manual ......................... 196

International Red Cross Assistance in IndoChina ........................... 197 World Red Cross Day: "You and Your Environment " ........................... 205

Dissemination of the Geneva Conventions: USSR - Guyana - Ireland - Jordan ......... 208

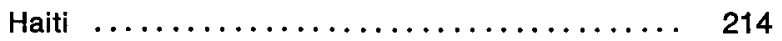

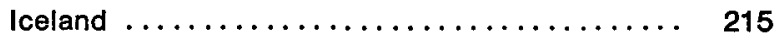

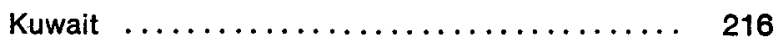

World Health Day $\ldots \ldots \ldots \ldots \ldots \ldots \ldots \ldots, 217$ 
FAENCH EDITION OF THE REVIEW

\section{SUPPLEMENTS}

TO THE REVIEW

\section{SPANISH}

\section{GERMAN}

INTERNATIONAL

REVIEW OF THE RED CROSS
The French edition of this Review is issued every month under the title of Revue Internationale de la Croix-Rouge. It is, in principle, Identical with the English edition and may be obtained under the same conditions.

Conferencia de expertos gubernamentales - Segunda reunión (II) - Algunas cifras referentes a los envios de socorros efectuados por el CICR durante 1972 - Reuniones de grupos limitados de expertos - América Latina.

Dieter Fleck : Die Verwendung von Rechtsberatern und Rechtslehrern in den Streitkräften - Einige Zahlen betreffend die im vergangenen Jahr vom IKRK versandten Hilfsgüter - Tagungen begrenzter Gruppen von Experten - Neubewertung der Rolle des Roten Kreuzes.

The International Review is published each month by the International Committe of the Red Cross

7, avenue de la Paix, CH - 1211 Geneva

Postal Cheque No. 121767

Annual subscription: Sw. Fr. 30.- (\$8)

Single copies Sw. Fr. 3. $-(\$ 0.80)$

Editor : J.-G. LOSSIER

The International Committee of the Red Cross assumes responsibility only for material over its own signature. 